\title{
Drivers of Bromus tectorum Abundance in the Western North American Sagebrush Steppe
}

\author{
Tyler J. Brummer, ${ }^{1}$ Kimberley T. Taylor, ${ }^{2}$ Jay Rotella, ${ }^{3}$ Bruce D. Maxwell, ${ }^{2}$ \\ Lisa J. Rew, ${ }^{2}$ and Matt Lavin ${ }^{4 *}$
}

\begin{abstract}
${ }^{1}$ Bioprotection Research Centre, Lincoln University, Canterbury, New Zealand; ${ }^{2}$ Land Resources and Environmental Sciences Department, Montana State University, Bozeman, Montana 59717, USA; ${ }^{3}$ Ecology Department, Montana State University, Bozeman, Montana 59717, USA; ${ }^{4}$ Plant Sciences and Plant Pathology Department, Montana State University, Bozeman, Montana 59717, USA
\end{abstract}

\begin{abstract}
Bromus tectorum can transform ecosystems causing negative impacts on the ecological and economic values of sagebrush steppe of the western USA. Although our knowledge of the drivers of the regional distribution of $B$. tectorum has improved, we have yet to determine the relative importance of climate and local factors causing $B$. tectorum abundance and impact. To address this, we sampled 555 sites distributed geographically and ecologically throughout the sagebrush steppe. We recorded the canopy cover of $B$. tectorum, as well as local substrate and vegetation characteristics. Boosted regression tree modeling revealed that climate strongly limits the transformative ability of $B$. tectorum to a portion of the sagebrush steppe with dry summers (that is, July
\end{abstract}

Received 10 February 2015; accepted 5 March 2016; published online 10 June 2016

Electronic supplementary material: The online version of this article (doi:10.1007/s10021-016-9980-3) contains supplementary material, which is available to authorized users.

Data relevant to this article posted at http://www.montana.edu/mlavin/ data/brtesites.txt.

Author Contributions Tyler J. Brummer conceived of/designed study; contributed new methods/models; performed research; analyzed data; wrote paper. Kimberley T. Taylor conceived of/designed study; contributed new methods/models; performed research; wrote paper. Jay Rotella conceived of/designed study; contributed new methods/models; analyzed data; wrote paper. Bruce D. Maxwell conceived of/designed study; performed research; wrote paper. Lisa J. Rew conceived of/designed study; performed research; wrote paper. Matt Lavin conceived of/ designed study; contributed new methods/models; performed research; analyzed data; wrote paper.

*Corresponding author; e-mail: mlavin@montana.edu precipitation $<10 \mathrm{~mm}$ and the driest annual quarter associated with a mean temperature $>15^{\circ} \mathrm{C}$ ) and low native grass canopy cover. This portion includes the Bonneville, Columbia, Lahontan, and lower Snake River basins. These areas are likely to require extreme efforts to reverse $B$. tectorum transformation. Our predictions, using future climate conditions, suggest that the transformative ability of $B$. tectorum may not expand geographically and could remain within the same climatically suitable basins. We found $B$. tectorum in locally disturbed areas within or adjacent to all of our sample sites, but not necessarily within sagebrush steppe vegetation. Conversion of the sagebrush steppe by B. tectorum, therefore, is more likely to occur outside the confines of its current climatically optimal region because of site-specific disturbances, including invasive species control efforts and sagebrush steppe mismanagement, rather than climate change.

Key words: cheatgrass; climate; disturbance; fire; native grass abundance; sagebrush biome.

\section{INTRODUCTION}

Bromus tectorum, cheatgrass, occupies large expanses of sagebrush steppe in western North America (Bradley 2009), where its dominance in the understory negatively affects the abundance and diversity of native shrubs, bunchgrasses, and herbaceous plant species (for example, Young and 
Clements 2009). A positive feedback between $B$. tectorum and fire exacerbates this negative impact, which further increases $B$. tectorum abundance (for example, Mack 2011). The causes of pre-fire dominance of $B$. tectorum in the sagebrush steppe have been attributed to the long history of intense overgrazing of native herbs and bunchgrasses (for example, Young and Clements 2009) and the destruction of biological soil crusts (for example, Reisner and others 2013). However, large-scale regional differences in $B$. tectorum dominance within the sagebrush steppe suggest other drivers must also be important, given that overgrazing is widespread in the sagebrush steppe.

Mounting evidence suggests that climate is an important factor affecting the ability of $B$. tectorum to invade and transform sagebrush steppe into plant communities dominated by annual species. For example, B. tectorum dominance is not expected in upper elevation mountain big sagebrush steppe with summers of high precipitation and cool temperatures (for example, Chambers and others 2014a, b). Other studies have pointed to high winter precipitation combined with summer drought as the necessary conditions favoring the ability of this winter annual to dominate and thus potentially transform sagebrush steppe (for example, Knapp 1996; Bradford and Lauenroth 2006; Bradley 2009; Bradley and others 2009; Leger and others 2009; Zelikova and others 2013; Taylor and others 2014). These particular climate regimes are most likely to occur in Wyoming big sagebrush steppe (for example, Chambers and others 2014a, b; Davies and others 2014). However, we still do not know how general these findings are across the entire sagebrush biome, how much variation there is within and between sagebrush associations, nor have these predictions been ground-validated with actual field measurements of $B$. tectorum abundance.

Our field studies of plant biodiversity in the western North American sagebrush steppe have revealed that within just Wyoming big sagebrush steppe, B. tectorum dominance is far from ubiquitous (Brummer and others 2013; Lavin and others 2013a, b; Quire 2013; Taylor and others 2014). For example, in the Wyoming big sagebrush steppe of the upper Snake River plains of southeastern Idaho, B. tectorum, although present, does not dominate no matter the local conditions-including following fire (Taylor and others 2014).

We expanded field studies of B. tectorum abundance to include the entire geographical dimension of the western North American sagebrush steppe. We test the hypotheses that the transformative ability of $B$. tectorum has been limited to a distinct geographical subset of sagebrush steppe and, given a long history of overgrazing throughout this biome that climate is the primary driver of $B$. tectorum dominance and impact. This study represents the first regional scale survey and modeling of $B$. tectorum abundance using on-the-ground measurements. Understanding the most important drivers of $B$. tectorum abundance will help us predict the current and future distribution and impact of $B$. tectorum, and help narrow down precisely where this annual grass is a potentially significant invasive plant species.

\section{Methods}

\section{Sample Sites}

Our reconnaissance fieldwork informed the design and site-selection variables for this study. Beginning with a plant biodiversity survey of intact sagebrush steppe within the Walker River area of California and Nevada (Lavin 1983) during 1980, we continued after 2003 in the central and northern regions of the biome (Seipel 2006; Lavin and Seibert 2011; Lavin and others 2013a, b; Quire 2013). During 2003-2015, we sampled 24 megatransects that ranged in length from 48 to $1207 \mathrm{~km}$ (Supplemental Figure 1; Supplemental Table 1). We located megatransects along primary and secondary highways and main gravel roads. Using main roads facilitated multi-year acquaintance with study sites. We found that the ecological condition of sagebrush steppe near main roads (but away from road verges), as measured by an abundance and diversity of native shrub, herb, and grass species, was equivalent to that located at remote sites (M. Lavin, personal observation).

Along each megatransect, when we haphazardly sampled sites each time, one of our pre-defined local variables changed (for example, from unburned to burned or from tall- to short-statured sagebrush steppe; Table 1; variables 18-26). Sample sites ranged 5-51 per megatransect and totaled to 555 (Supplemental Figure 1; Supplemental Appendix 1). The range in length and number of sample sites per megatransect was due to the patchiness of sagebrush steppe (for example, Welch 2005). We did not locate our sample sites prior to field work because digital data layers of our local variables do not exist for the entire area of interest. We posted photographs of sample sites to https:// www.flickr.com/photos/plant_diversity/collections/ $72157635340665540 /$.

At each sample point, we delineated a 1-hectare area of sagebrush steppe away from the road such that $B$. tectorum abundance along the roadside, 
Table 1. The 27 Predictor Variables of Bromus tectorum Canopy Cover, Which Were Scored for All 555 Sample Sites

\begin{tabular}{|c|c|}
\hline Predictor & Comments \\
\hline Climate variables & $\begin{array}{l}\text { The source for the climate data: WorldClim } 2.5 \text { arc-minute } \\
\text { scale (www.worldclim.org; Hijmans and others 2005) and } \\
\text { PRISM (http://www.prism.oregonstate.edu/; PRISM Cli- } \\
\text { mate Group 2015) }\end{array}$ \\
\hline 1. Mean diurnal range (Bio2) & $\begin{array}{l}\text { Mean monthly maximum minus mean monthly minimum } \\
\text { temperatures }\end{array}$ \\
\hline 2. Isothermality (Bio3) & $\begin{array}{l}\text { Day-to-night temperature oscillations relative to the sum- } \\
\text { mer-to-winter oscillations: }(\text { Bio } 2 /(\operatorname{Bio} 5-\operatorname{Bio6})) * 100 \text {. }\end{array}$ \\
\hline $\begin{array}{l}\text { 3. Annual temperature range } \\
\text { (Bio7) }\end{array}$ & $\begin{array}{l}\text { The difference between maximum mean temperature dur- } \\
\text { ing the warmest month (bio5) and minimum mean } \\
\text { temperature during the coldest month (bio6) }\end{array}$ \\
\hline $\begin{array}{l}\text { 4. Mean temperature of wettest } \\
\text { quarter (Bio8) }\end{array}$ & The wettest quarter $(\mathrm{C})$ was determined for each sample site \\
\hline 5. Mean temperature of driest & The driest quarter $(\mathrm{C})$ was determined for each sample site \\
\hline
\end{tabular}

6. Annual precipitation (mm; Biol2)

7. Precipitation of driest month (Biol4)

8. Precipitation seasonality (Biol5)

9. Precipitation of coldest quarter (biol9)

10. April precipitation $(\mathrm{mm})$

11. May precipitation $(\mathrm{mm})$

12. July precipitation $(\mathrm{mm})$

13. October precipitation $(\mathrm{mm})$

14. January maximum temperature $(\mathrm{C})$

15. March maximum temperature $(\mathrm{C})$

16. January minimum temperature $(\mathrm{C})$

17. July minimum temperature (C)

Local variables

18. Agropyron cristatum dominance

19. Dominant shrub

20. Native grass canopy cover

21. Native herb canopy cover

These variables except for "drainage class" were assigned during field work

Where Agropyron cristatum is the dominant grass, Bromus tectorum tends to be absent or rare (for example, Lavin and others 2013a, b)

Our sample sites within the sagebrush steppe were dominated mainly by one of 14 taxa of shrubby and subshrubby Artemisia, one of three species of other shrubby Asteraceae, or one of 7 shrubby species of Amaranthaceae or Sarcobataceae

An abundance of perennial native grasses and herb might serve as proxies for the degree of historical disturbance

An abundance and diversity of native perennial herbs suggests a history of minimal disturbance (for example, Lavin and others $2013 \mathrm{a}, \mathrm{b}$ ) 
Table 1. continued

\begin{tabular}{lc}
\hline Predictor & Comments \\
\hline 22. Fire & The presence of charred stumps, resprouting shrub species, abundant Chrysothamnus \\
& viscidiflorus, or low sagebrush canopy cover suggests a site with a recent burn \\
& history. Most shrubby Artemisia species including Artemisia tridentata do not re- \\
& sprout after they burn and require decades if not a century or more to reestablish a \\
& site via seed (for example, Baker 201 l; Cooper and others 2011) \\
& Physiognomic stature of sagebrush steppe may positively correlate with substrate \\
& water-holding capacity (for example, Tisdale and Hironaka 1981). Short-statured \\
23. Shrub stature & sagebrush steppe could indicate a site environment too arid to support abundant $B$. \\
& tectorum \\
& Source: http://websoilsurvey.sc.egov.usda.gov/App/WebSoilSurvey.aspx, USDA \\
& NRCS Web Soil Survey \\
24. Drainage class & Sandy sites tended to be devoid of B. tectorum \\
25. Sandy substrate & Exposed base rock, usually basalt, tended to harbor abundant B. tectorum
\end{tabular}

Site variables

27. Sampling year

Reconnaissance of the megatransects and sample sites occurred during 2003-2015 with multi-year visits to each site

Longitude and latitude

A semivariogram was constructed for all boosted regression tree models of B. tectorum abundance in order to test for spatial autocorrelation of the residual B. tectorum cover data (R package geoR; Ribeiro and Diggle 2015). No significant spatial autocorrelation was detected at the 50 and $200 \mathrm{~km}$ scale (Supplemental Figures 3 and 4)

The dataset of 555 sample sites by 135 site descriptors and predictor variables is posted to http://www.montana.edu/mlavin/data/brtesites.txt (Supplemental Appendix 1).

which is likely associated with some site-specific disturbance (for example, road grading, mowing, and herbicide application), was not sampled. In every case $B$. tectorum inhabited the roadside but not necessarily the nearby sagebrush site. Restricting our sampling of sagebrush steppe to sites that either harbored or were adjacent to stands of $B$. tectorum removed the potential for dispersal limitation to confound our results.

Our sampling protocol targeted sagebrush steppe in open expanses, on gentle topography, and not adjacent to forests and woodlands, which limited local influences such as slope and aspect. Most of our sites showed evidence of historical or current overgrazing, as is common across the entire biome (for example, Young and Sparks 2002; Welch 2005; Young and Clements 2009; Davies and others 2011). This evidence included trampling, low native grass canopy cover, and low native perennial herb and shrub diversity. Because disturbance, inclusive of grazing, lowers the resistance of sagebrush steppe to $B$. tectorum invasion (Anderson and Inouye 2001; Bradford and Lauenroth 2006; Chambers and others $2014 a, b)$, we assumed that the intensity and history of grazing were homogeneous throughout the sagebrush steppe and across all of our sample sites. Our sample sites had no visible evidence of heavy human disturbances, such as invasive species control efforts via local herbicide application, localized sagebrush eradication efforts, or construction and energy exploration projects.

We also sampled recently burned sagebrush vegetation. These sites included, for example, the July 2010 Jefferson fire on the Idaho National Lab ( 109,000 acres) with little if any B. tectorum recolonizing as of September 2015, and the July 2012 Long Draw Fire in southeastern Oregon $(557,648$ acres) with $B$. tectorum as abundant in unburned as in burned sagebrush steppe as of September 2015. Our multi-year acquaintance with these and all our sample sites ensured that our recorded abundances reflected long-term conditions.

Our sagebrush steppe sample sites were dominated by shrub and subshrubs including species of Artemisia, Atriplex, Chrysothamnus, Ericameria, Eriogonum, Grayia, Haplopappus, Krascheninnikovia, Leptodactylon, Sarcobatus, and Tetradymia (taxonomic nomenclature follows Cronquist and others 1972 through Holmgren and others 2012, and Lesica 2012). The 14 taxa of shrubby and subshrubby Artemisia that dominated or co-dominated our study sites included $A$. arbuscula (little sagebrush), A. bigelovii (dwarf sagebrush), A. cana subsp. cana and subsp. viscidula (silver sagebrush), A. filifolia (sand sagebrush), A. frigida (fringed sagebrush), $A$. nova (black sagebrush), $A$. pedatifida (birdsfoot sagebrush), A. pygmaea (pygmy sagebrush), A. spinescens (bud sagebrush), Artemisia tridentata subsp. 
tridentata (basin big sagebrush), Artemisia tridentata subsp. vaseyana (mountain big sagebrush), A. tridentata subsp. wyomingensis (Wyoming big sagebrush), or A. tripartita (three-tip sagebrush).

\section{The Response}

We recorded canopy cover of B. tectorum within sagebrush steppe vegetation using the Daubenmire method (Daubenmire 1959; Coulloudon and others 1999). We estimated canopy cover within l-hectare plots using 20 randomly positioned Daubenmire frames $(20$ by $50 \mathrm{~cm}$ ) viewed from directly above. We modified the Daubenmire cover classes to include a canopy cover class of " 0. " Our multiyear reconnaissance of all 555 study sites ensured that our one-time scoring of abundance did not reflect a period of below-average annual precipitation or other idiosyncrasies. Daubenmire cover classes were converted during data analyses to midpoint proportions: $0=0,1=2.5 \%, 2=15 \%$, $3=37.5 \%, 4=62.5 \%, 5=85 \%$, and $6=97.5 \%$. We wanted our response variable to differentiate areas that generally harbored high levels of $B$. tectorum canopy cover versus areas with only trace amounts. This would be an indication of where sagebrush steppe is potentially permanently transformed into introduced annual plant communities (for example, D'Antonio and Vitousek 1992; Parker and others 1999; Brooks and others 2004; McDonald and others 2009; Bradley 2013).

\section{Predictor Variables}

The variables we hypothesized a priori to be potentially important for predicting the abundance of $B$. tectorum within sagebrush steppe vegetation related to the regional climate and local biotic and abiotic factors. We analyzed 27 variables, which included one site variable (sampling year), 17 climate variables (reduced from 55 bioclimatic and monthly precipitation and temperature variables following a pairwise correlation analysis; Supplemental Figure 2), and nine local variables (Table 1). We recorded canopy cover of native grasses and native perennial herbs, two of our local variables, as described above for B. tectorum. We generated raster layers for bioclimatic variables from the PRISM ( $4 \mathrm{~km}$ resolution; PRISM Climate Group 2015) and WorldClim (2.5 arc-minute resolution; Hijmans and others 2005) precipitation and temperature raster layers using the $\mathrm{R}$ statistical program (R Core Team 2015) and the dismo package (Hijmans and others 2015a). We extracted precipitation and temperature model estimates from the PRISM and WorldClim layers with the raster package (Hijmans and others 2015b) using GPSobtained longitude and latitude of the midpoint for each of our 555 sample sites. The PRISM data encompass our sampling years 2003-2014 and the WorldClim data encompass the years 2061-2080. We produced bioclimatic variables (for example, O'Donnell and Ignizio 2012) using the biovars function in the $\mathrm{R}$ package dismo (Hijmans and others 2015a).

\section{Modeling Approach}

We used a boosted regression tree (BRT) approach to determine the importance of climate and local biotic and abiotic factors in predicting the abundance of B. tectorum within the sagebrush steppe. BRT modeling involves highly flexible algorithms that overcome many of the shortcomings of traditional linear modeling and model selection (Elith and others 2008). BRTs produce powerful models by building many simple classification/regression trees in sequence, each time explaining more of the residual variation in the dataset until reaching the optimal prediction error. BRT modeling allows for non-linear responses and interactions among variables. They are also robust to multicollinearity of predictors and outliers. The approach avoids overfitting by identifying the tradeoff between prediction accuracy and generalizability using crossvalidation, assuming an appropriately defined outof-sample population. All BRT analyses involved the "brt.step" function in the "dismo" package (Hijmans and others 2015a).

Appropriately formulating the cross-validation procedure is the key for assuring the estimates of model predictive power and generalizability are accurate (Wenger and Olden 2012). Spatial autocorrelation in environmental predictors can lead to overestimates of model predictive performance, so we adopted a fivefold cross-validation procedure that randomly selected megatransects to be assigned to folds. Because we defined megatransects by region, training data in the cross-validation routine were never close to the data used for testing and this ensured that our estimates of model performance were not biased by spatial autocorrelation. To assess model performance and generalizability, we used prediction $R^{2}$ (cross-validation $R^{2}$ abbreviated $R^{2} \mathrm{cv}$; Efron 1983). $R^{2} \mathrm{cv}$ is the prediction residual sums of squares divided by the null sums of squares, and thus represents the best estimate of the model's ability to predict to independent data.

Our first analysis determined the predictor variables that significantly improved model performance, enabling us to select variables for cur- 


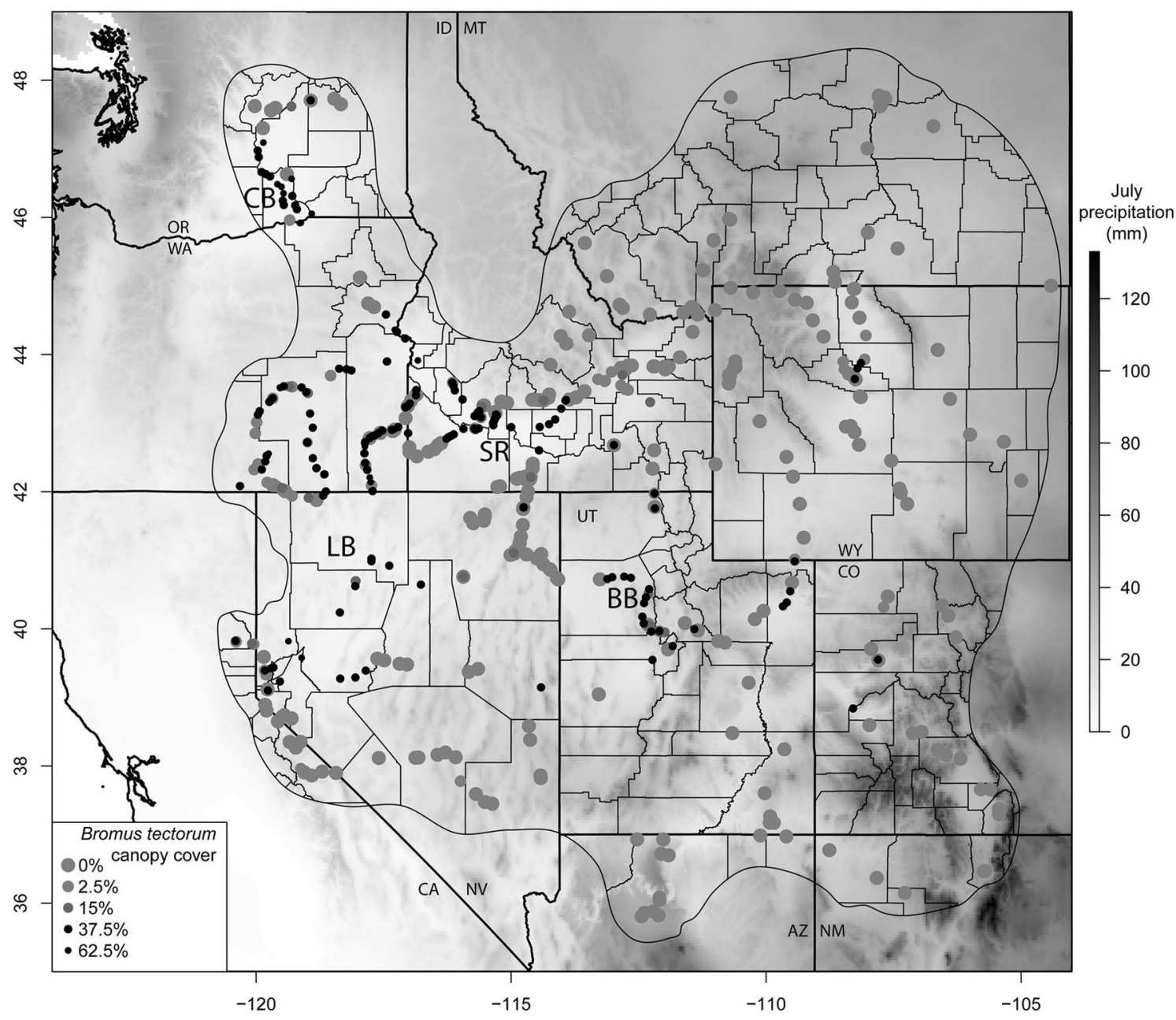

Figure 1. Location of the 555 sample sites within the sagebrush steppe of western North America (bounded by the polygon) with an indication of $B$. tectorum canopy cover. The western U.S.A. state labels include: $A Z$ Arizona, $C A$ California, CO Colorado, ID Idaho, MT Montana, NM New Mexico, NV Nevada, OR Oregon, UT Utah, WA Washington, WY Wyoming. The four main low-elevation basins include the Bonneville (BB), Columbia (CB), Lahontan and adjacent Pleistocene lake (LB), and lower Snake River (SR) basins.

rent and future predictions. We carried out an analysis that removed each variable individually from the full model. The change in $R^{2} \mathrm{Cv}$ between the full model and a model with one variable removed was compared using a $t$ test. The fivefold cross-validation routine was carried out 50 times, with megatransects being randomly assigned to different folds at each run in order to capture the variation in $R^{2} \mathrm{cv}$ dependent on fold assignment. The stochastic model fitting error is also included in this variation, although other analyses that separated the two showed it was much smaller than the variation from fold assignment. After Bonferroni correction, we retained variables in the final model if $R^{2} \mathrm{cv}$ was significantly degraded with its exclusion (a one-sided $t$ test was performed to look at model degradation rather than model improvement).

Our second analysis determined the relative importance of the set of predictor variables selected from the single-variable removal analysis. Relative importance is a measure of how often a variable is used in the splitting algorithm as well as the amount of variation accounted for by the split, thus we used it as a measure of the effect size of each predictor. The fivefold cross-validation routine was randomized 500 times to estimate the $95 \%$ quantile intervals of relative importance. 


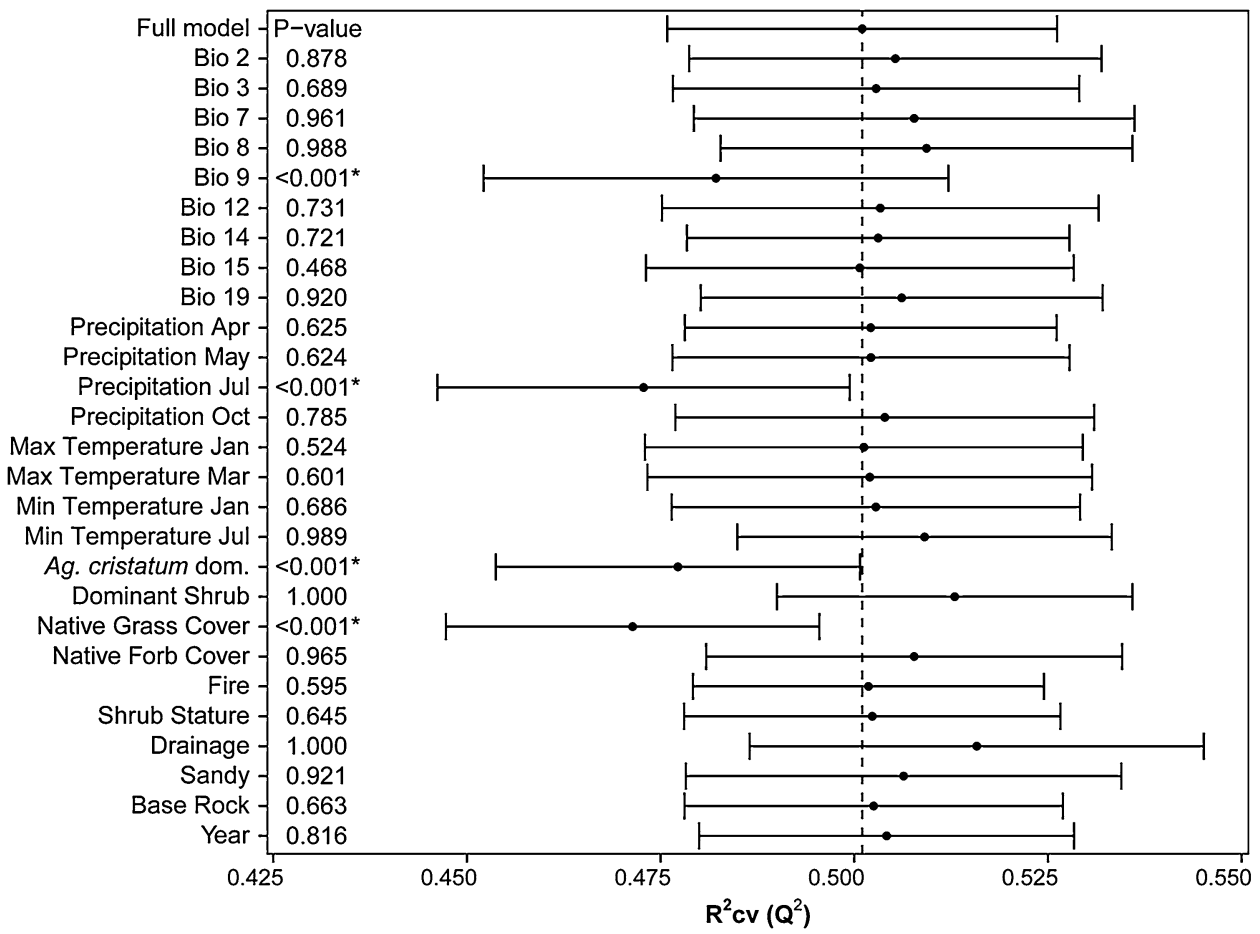

Figure 2. Model predictive performance as measured by $R^{2} \mathrm{cv}\left(\mathrm{Q}^{2}\right)$ for the full model (containing all predictors) compared to models with one predictor removed. The top point and associated error bars represent the mean (vertical dashed line) and \pm 1 standard deviation of the $R^{2} \mathrm{cv}$ of the full model. The other points and associated error bars are for models with one predictor removed (reported on the $y$-axis). The $P$ value column reports the significance of a Bonferroni-corrected onesided $t$ test between the full model $R^{2} \mathrm{cv}$ and the model with one predictor removed. An asterisk indicates a predictor whose removal significantly lowered model performance.

\section{Prediction Mapping}

We generated prediction maps under current and future climate scenarios using BRT models of $B$. tectorum canopy cover as a function of climate variables with the "predict" function in the raster package. We used the 2003-2014 PRISM climate grids for current climate scenarios. The 2061-2080 WorldClim models (http://www.worldclim.org/ cmip5_2.5m) provided future estimates of climate conditions. These involved the downscaled global climate model (GCM) data from CMIP5 (IPPC Fifth Assessment), at 2.5 arc-minutes resolution (rcp45). Future WorldClim models included CCSM4, CNRM-CM5, GFDL-CM3, GFDL-ESM2G, GISS-E2$\mathrm{R}$, HadGEM2-AO, INMCM4, IPSL-CM5A-LR, MIROC-ESM, and MPI-ESM-LR. We chose these 10 to best align with those used by Bradley (2009). Following Beaumont and others (2008), Buisson and others (2010), Mote and others (2011), and Vano and others (2015), we analyzed the output of each of these 10 different future climate models to generate composite prediction maps, which included the minimum, mean, maximum, and stan- dard deviation of predicted future abundances of $B$. tectorum.

To determine the degree of projection into novel covariate space on our prediction maps, we used the extrapolation detection (ExDet) program, which determines extrapolation based on the Mahalanobis distance (Mesgaran and others 2014). We generated raster layers of individual climate variables as scored for each of our 555 sample sites. We used these layers as the reference data. Our projection data comprised raster layers for each of the climate variables derived from current (PRISM) and future (WorldClim) climate models for the sagebrush biome. By combining the reference and projection data, we were able to inspect the prediction maps for the location and extent of type 1 (univariate) and type 2 (multivariate) novelty.

\section{Limits of Our Study}

Given our large geographic scope, we limited local site variables to those we could collect uniformly across the entire study area and that did not vary at scales smaller than 1 hectare, such as soil temper- 


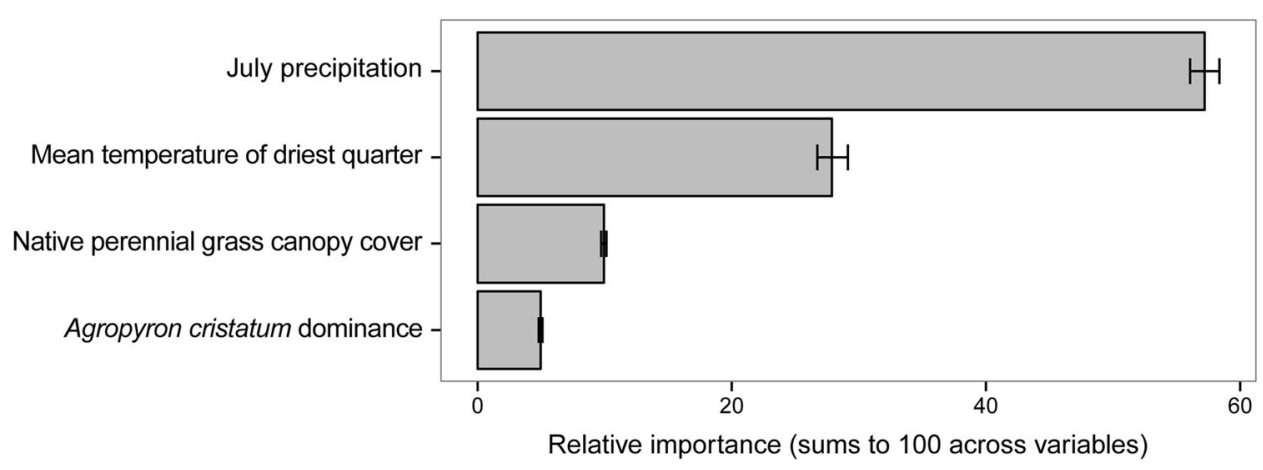

Figure 3. Relative importance of the four variables that were retained in the model after the one-variable-removal analysis (Figure 2). Relative importance sums to 100 across the four variables. The $95 \%$ error bars were calculated from the empirical quantiles of 500 runs of the model fitting routine, randomizing transect assignment to folds between runs. Thus, it incorporates variation due to the cross-validation and model fitting.

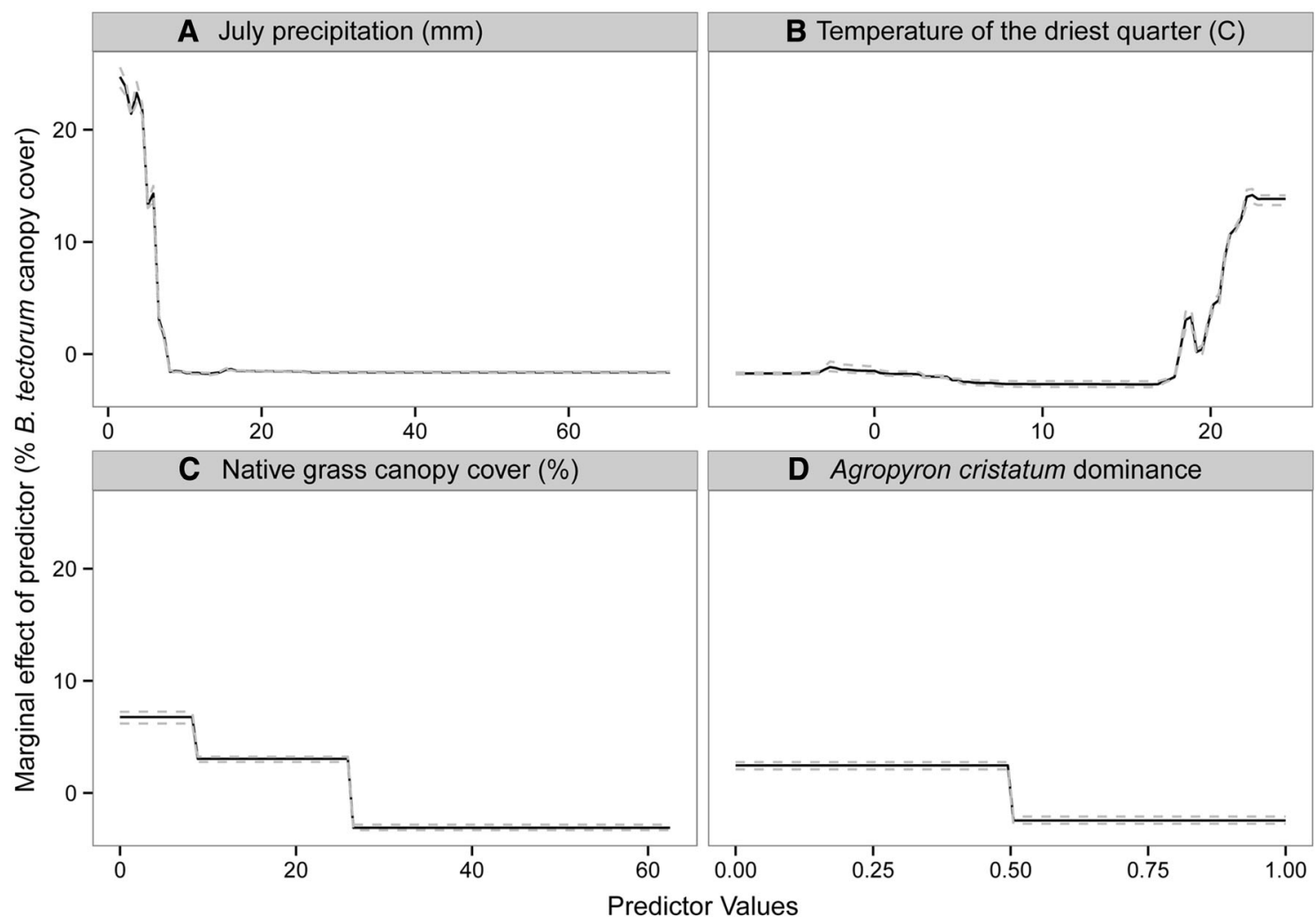

Figure 4. Partial dependence plots illustrating the associations in the final model between B. tectorum abundance and: A. July precipitation; B. mean temperature of the driest quarter; C. native grass canopy cover; D. Agropyron cristatum present as the dominant grass species. The $y$-axis is B. tectorum abundance across different levels of the predictor variable holding all other predictors at their mean values. The fitted functions are from one realization of the model fitted using fivefold whole transect selection cross-validation. The black line is the mean response. The dashed gray lines are the $95 \%$ quantile intervals.

ature and moisture. Thus, we did not classify our sites into types of vegetation other than recording the most dominant 2-3 shrub and grass species. We also did not sample substrate data other than for gross characteristics (Table 1, variable \#'s 24-26). We also limited our scoring of canopy cover to $B$. tectorum, native perennial herbs, and native grasses. 

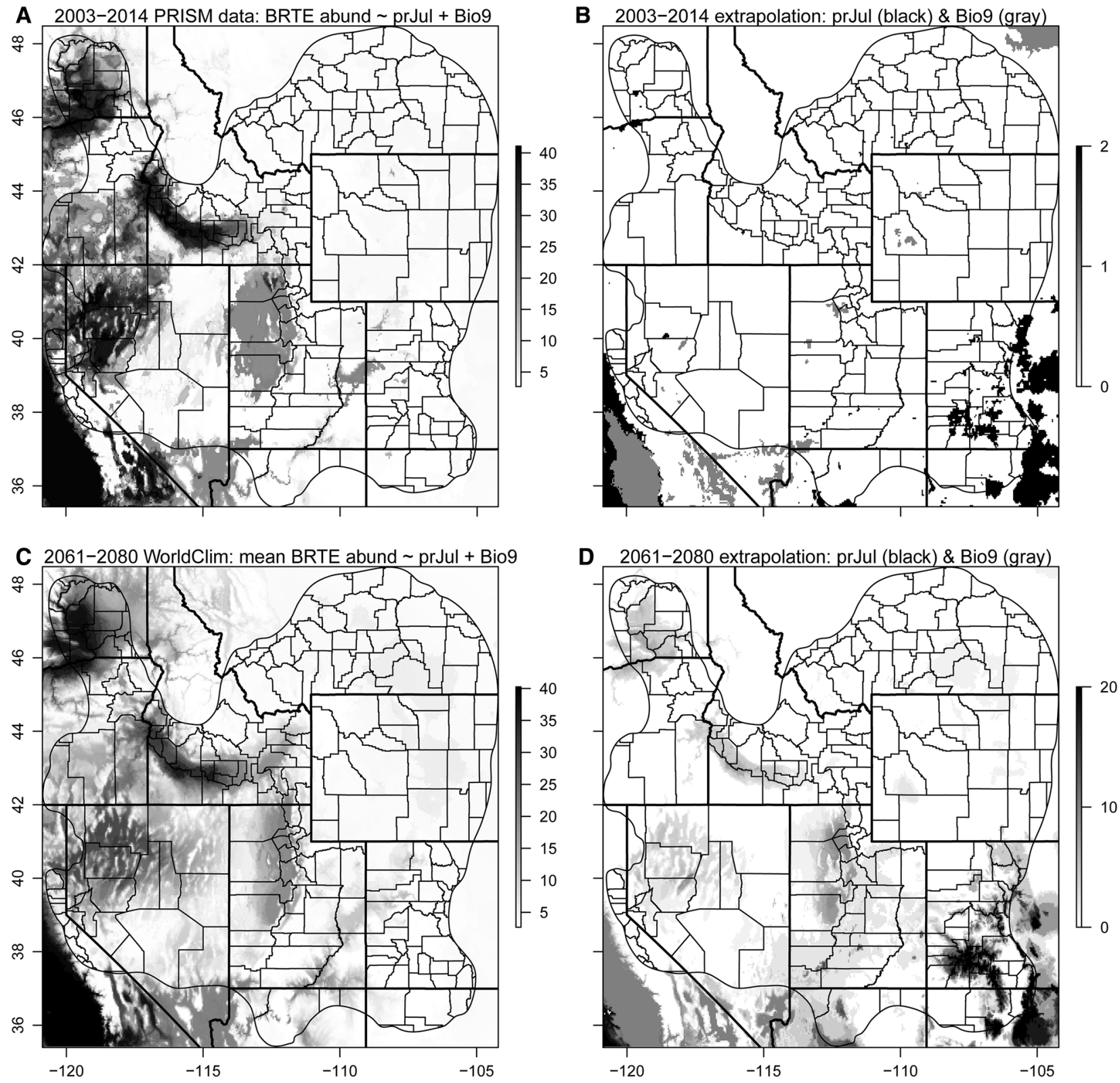

Figure 5. Prediction and extrapolation detection maps of B. tectorum canopy cover (BRTE abund) or where it is potentially transformative of the sagebrush steppe (bounded by the polygon). A. Predicted current canopy cover as a function of July precipitation (prJul) and bioclimatic variable 9 (Bio9). Scale bar refers to \% canopy cover of B. tectorum. B. Extrapolation detection analysis of current climate data revealing mostly univariate novelty within the sagebrush steppe. Scale bar refers to Bio9 scored as 1 and prJul scored as 2. C. Predicted future canopy cover. Scale bar refers to \% canopy cover of $B$. tectorum. D. Extrapolation detection analysis of future climate revealing mostly univariate novelty within the sagebrush steppe. Because extrapolation is mostly univariate, the degree of gray shading $(1-10)$ represents the consistency of regions of Bio9 extrapolation and the degree of black shading (11-20) represents the consistency of regions of prJul extrapolation. See Figure. 1 for the western U.S.A. state labels.

\section{RESULTS}

Of our 555 sample sites, 186 had a canopy cover of B. tectorum of at least $25 \%$ (Daubenmire cover class 33; Figure 1). Of these 186, 145 were dominated by
Wyoming big sagebrush, 15 were dominated by shrubby Chrysothamnus or Ericameria in otherwise Wyoming big sagebrush steppe, and 16 sites were dominated by salt desert shrubs in the Amaran- 
thaceae and Sarcobataceae that were adjacent to Wyoming big sagebrush steppe. Thus, 176 of the 186 sample sites with a high abundance of B. tectorum came from Wyoming big sagebrush steppe and associated shrub steppe vegetation.

\section{Predictor Variables of B. tectorum Abundance}

Our analysis identified July precipitation, mean temperature of the driest quarter (Bio 9), native grass canopy cover, and the dominance of Agropyron cristatum as the significant predictors of $B$. tectorum abundance across the sagebrush steppe biome (Figure 2). The final model with four variables had an $R^{2}$ cv of 0.49 (95\% confidence interval from 0.44 to 0.55 from the quantiles of 500 randomizations of the transect assignment to folds). July precipitation was the most important, followed by mean temperature during the driest quarter (Bio 9; Figure 3). Two variables associated with biotic interactions, native grass canopy cover and Agropyron cristatum as the dominant grass, had significant effects on $B$. tectorum canopy cover (Figures 2, 3). Canopy cover of B. tectorum was related to July precipitation and mean temperature of the driest quarter in a threshold-type response. Sites with less than $10 \mathrm{~mm}$ of July precipitation and temperatures of the driest annual quarter generally greater than 15C were associated with high B. tectorum abundance (Figure 4A, B; Supplemental Figure 5). Canopy cover of native grasses of at least $25 \%$ was associated with little or no canopy cover of B. tectorum (Figure 4C). Agropyron cristatum as the dominant grass corresponded to low abundance of B. tectorum (Figure 4D).

\section{Predicting Current and Future Impact}

Where B. tectorum potentially can transform expanses of sagebrush steppe mainly in four large low-elevation basins (Figure 5A). These include the Bonneville Basin of mainly central Utah, the Columbia Basin of mainly southeastern Washington, the Lahontan and nearby Pleistocene lake basins (for example, Alvord, Meinzer, Surprise, Warner) of the northwestern quadrant of Nevada and adjacent northeastern California and southeastern Oregon, and the lower Snake River plains of southwestern Idaho and adjacent Oregon. Minor regions of high abundance $B$. tectorum within sagebrush steppe include the Big Horn Basin of northcentral Wyoming and low-elevation regions along the border of Utah and Colorado (Figure 5A; for example, around Vernal, Dinosaur National Monument, and Grand Junction). Our extrapolation detection analysis on the current climate conditions revealed little type 1 (univariate) and essentially no type 2 (multivariate) novelty within the sagebrush steppe (Figure 5B).

Where B. tectorum potentially can transform expanses of sagebrush steppe could possibly remain within the main large geographical basins where most of the transformation has already occurred (Figure 5C; Supplemental Figure 6). The eastern and southern tiers of the sagebrush steppe, which include large expanses of Wyoming big sagebrush steppe, are not predicted to be vulnerable to transformation by $B$. tectorum. Our extrapolation detection analysis suggested little if any type 2 (multivariate) novelty. Of the type 1 (univariate) novelty for the future prediction, we are extrapolating to some degree within the Columbia, Bonneville, Lahontan, and Lower Snake River Basins with respect to mean temperature of the driest quarter (Bio9; Figure 5D).

We did not detect a significant relationship of $B$. tectorum abundance with burn status (burned vs. unburned) and abundance of perennial native herbs (Table 1, variables 22 \& 26). Our sampling design specifically included geographically proximal sample sites that differed with respect to these two variables. These results (Figure 2) confirm our field observations across the sagebrush steppe that sites in close proximity that differ in burn status and perennial native herb abundance tend to have similar levels of B. tectorum canopy cover.

\section{Discussion}

Our study suggests that climate places a geographical constraint on the transformative ability of B. tectorum within the sagebrush steppe biome (Figures 1, 5A). Much of the sagebrush steppe remains unaffected by B. tectorum in spite of a long history throughout the biome of intensive livestock grazing, range conversion and improvement projects, grazing management programs (Twain 1872; Douglas 1961; Carson 1962; and Young and Sparks 2002; Young and Clements 2009), a recent increase in fire frequency (Baker 2011), and energy extraction and exploration (for example, Davies and others 2011). This degree of disturbance, which has led to the current degraded and fragmented condition of the sagebrush steppe (Knick 1999; Welch 2005), has not necessarily augmented the transformative ability of $B$. tectorum.

This interpretation stands in contrast to the finding that many semi-arid ecosystems in western 
North America have been transformed to plant communities dominated by exotic annuals (for example, D'Antonio and Vitousek 1992; Suding and others 2004; Jones and Monaco 2009; Davies and others 2012; Bagchi and others 2013). Our study suggests that $B$. tectorum has a competitive advantage within sagebrush steppe vegetation only where dry summer conditions greatly impede native plant productivity. Most of the sagebrush steppe in western North America lacks this climatic condition. Studies centered on the sagebrush biome (for example, Bradley and others 2009; Chambers and others 2014a, b; Taylor and others 2014) suggest that cool or moist summers are limiting to $B$. tectorum abundance. Leger and others (2009) and Prevéy and Seastedt (2014) suggest that winter growth of $B$. tectorum provides its competitive edge against native plants in the sagebrush steppe. Knapp (1996) implicated that winter precipitation was maximum followed by dry summers, which reflect the Mediterranean climate conditions, where B. tectorum evolved, as explaining the success of this annual in the Great Basin. We find that sagebrush steppe has the greatest potential to shift irreversibly to $B$. tectorum dominance in the extensive low-elevation areas of the Bonneville, Columbia, Lahontan, and adjacent Pleistocene Lake (for example, Reheis 1999), and lower Snake River basins where summers are very arid (for example, July precipitation $<10 \mathrm{~mm}$ and mean temperature of the driest quarter $>15 \mathrm{C}$ ).

The transformative ability of B. tectorum is restricted to a geographical subset of Wyoming big sagebrush steppe and is mostly absent in sagebrush steppe dominated by other taxa of shrubby Artemisia. Mountain big sagebrush steppe (dominated by $A$. tridentata subsp. vaseyana) has summer precipitation that enhances perennial grass growth and impedes B. tectorum dominance, which facilitates its restoration (Davies and others 2011; Chambers and others 2014a, b; Nelson and others 2014; Knutson and others 2014). This must also be true of sagebrush steppe dominated by A. arbuscula, $A$. cana, or $A$. tripartita, which also occur in summer-productive settings. Similarly, sagebrush steppe dominated by A. bigelovii, A. filifolia, A. nova, $A$. pedatifida, or $A$. pygmaea has low potential for $B$. tectorum dominance because they also occur where the warm months are on average wetter than cold months of the year.

Artemisia spinescens never dominated any of our sample sites but always occurred within Wyoming big sagebrush steppe co-dominated by salt desert shrubs of the Amaranthaceae (Atriplex, Grayia, and Krascheninnikovia) and Sarcobataceae (Sarcobatus) or within pure salt desert vegetation. Such salt desert vegetation containing $A$. spinescens is not necessarily resistant to $B$. tectorum dominance (for example, Knapp 1996; Haubensak and others 2009; Young and Clements 2009; and Chambers and others 2014a). This is not surprising given that these vegetation types are common at the lower elevations of the Big Horn, Bonneville, Columbia, Lahontan, and lower Snake River basins. Outside of these basins, we found Wyoming big sagebrush steppe co-dominated by Amaranthaceae and Sarcobataceae shrubs or salt desert with $A$. spinescens to be devoid of $B$. tectorum. Thus, we conclude that climate is the important determinant of $B$. tectorum dominance in such sagebrush vegetation.

Our predictions of changes in B. tectorum abundance continue to show high abundance mainly in the Bonneville, Columbia, Lahontan, and Lower Snake River basins. Still and Richardson (2015) generally show Wyoming big sagebrush as having a $50-75 \%$ probability of contracting in these same four large basins by 2050. The potential warmer and drier future climates of these four large basins could cause the Wyoming big sagebrush steppe to become dominated by other shrubby species that are already locally common (for example, species of Atriplex, Grayia, Krascheninnikovia, other genera of Amaranthaceae and Sarcobataceae, other species of shrubby Artemisia, and other genera of shrubby Asteraceae). While Still and Richardson (2015) modeled the distribution of the taxon Artemisia tridentata subsp. wyomingensis, we are modeling the abundance of $B$. tectorum throughout the sagebrush steppe and associated shrub steppe vegetation. Our results suggest that the abundance of $B$. tectorum does not depend on Wyoming big sagebrush abundance, which is exemplified by the abundance of $B$. tectorum in salt desert vegetation from the aforementioned large basins.

Fire and native perennial herb abundance accounted for little of the variation of B. tectorum canopy cover over the entirety of the sagebrush biome. Geographically nearby sites differing in burn category generally had similar levels of $B$. tectorum abundance, which is consistent with the findings reported in Knutson and others (2014). This finding is inconsistent with the proposed importance of the positive feedbacks between fire and B. tectorum abundance. An increase in B. tectorum abundance increases fire frequency, which further increases $B$. tectorum abundance, biomass, or seed production (reviewed in Balch and others 2013; Taylor and others 2014). In contrast, Young and Clements (2009) suggest fire can sometimes reduce $B$. tectorum abundance at least during the 
short term. Because of climate constraints, post-fire B. tectorum abundance may simply be a function of pre-fire abundance in the sagebrush steppe.

Similarly, geographically neighboring sites differing in levels of perennial native herb canopy cover were chosen as part of our study design. Such site comparisons showed little differences in B. tectorum canopy cover. This contrasts to Chambers and others $(2007,2014 a, b)$, who found that high abundance of native perennial herbs was negatively correlated with $B$. tectorum abundance. However, Lavin and others (2013a) found that Wyoming big sagebrush steppe differing in degrees of disturbance and levels of $B$. tectorum abundance were occupied by different assemblages of native perennial herbs. Wyoming big sagebrush with frequent disturbance regimes harbored native perennials belonging to taxa such as Antennaria, herbaceous Artemisia, Fabaceae excepting Neo-Astragalus, Grindelia, Heterotheca, Malvaceae, Oxytropis, Rumex, Solidago, Symphyotrichum, and Vicia. These taxa were absent or rare in Wyoming big sagebrush steppe that was undisturbed and with little or no $B$. tectorum. These results are in line with those of Seefeldt and McCoy (2003), who found no relationship between disturbance regime via grazing and fire and the alpha diversity of herbaceous plant species in three-tip sagebrush (A. tripartita) steppe of southwestern Idaho. Therefore, the relationship of native perennial herb abundance and diversity with disturbance (including an abundance of $B$. tectorum as a proxy for disturbance) needs more investigation, especially with respect to beta diversity and phylogenetic beta diversity rather than alpha diversity (for example, Lavin and others 2013a).

\section{Conclusions}

Our findings suggest that B. tectorum is transformative only in a subset of the total range of the sagebrush steppe. Outside of the climatic conditions that promote $B$. tectorum invasiveness, it is likely to dominate only in areas of heavy physical disturbance (for example, Lavin and others 2013a). Thus, restoration efforts in these areas should limit disturbance (for example, conservative livestock grazing regimes). Direct interventions should focus on low disturbance methods such as broadcast seeding. Higher disturbance methods, such as drill seeding and herbicide use, are likely to be counterproductive given that they can impede native grass recovery (for example, Ratzlaff and Anderson 1995; Knutson and others 2014) and thereby increase $B$. tectorum abundance or the likelihood of reinvasion.

Within the climatic conditions where B. tectorum is highly abundant, restoration efforts will necessarily be more extreme and costly. We did find that Agropyron cristatum suppresses B. tectorum, which supports other's suggestions as using it as a tool in the assisted succession restoration method (for example, Cox and Anderson 2004; Young and Clements 2009; Blank and others 2015). However, the use of $A$. cristatum is controversial as it can become invasive and be a strong competitor of perennial bunchgrasses (for example, Gunnell and others 2010; Knutson and others 2014; Nafus and others 2015).

The mean projections of $B$. tectorum abundance under future climates suggest that this annual will remain transformative where it is at present but it is unlikely to dramatically expand the area where it transforms ecosystems. However, some of the climate projections indicated the potential for relatively large expansion of the area where $B$. tectorum is highly abundant. Thus, uncertainty remains regarding the future extent of the transformative ability of B. tectorum.

\section{ACKNOWLEDGEMENTS}

This study gained momentum during 2009-2011 field studies in the Idaho National Laboratory. We are grateful to Roger Blew of Gonzales-Stoller Surveillance, LLC, for facilitating the funding and logistics of that interval of our field studies (GSS0300-1,100,008). BDM and KTT were supported by NSF-WildFIRE PIRE, OISE 09667472. We also acknowledge Curt Freese, World Wildlife Fund, Randall Scott, Northern Arizona University, Arnold Tiehm, University of Nevada Reno, and Martin Wojciechowski, Arizona State University, for facilitating part of the fieldwork conducted during the course of this study. Antonia Hedrick, Bureau of Land Management, Boise, Idaho, first pointed out to us the dramatic landscape differences between the lower and upper Snake River Plains of southern Idaho. We thank the editors and two anonymous reviewers whose comments and suggestions greatly improved the presentation of this manuscript.

Conflict of Interest The authors declare that they have no conflict of interest. 


\section{REFERENCES}

Anderson JE, Inouye RS. 2001. Landscape-scale changes in plant species abundance and biodiversity of a sagebrush steppe over 45 years. Ecol Monogr 71:531-56.

Bagchi S, Briske DD, Bestelmeyer BT, Wu XB. 2013. Assessing resilience and state-transition models with historical records of cheatgrass Bromus tectorum invasion in North American sagebrush-steppe. J Appl Ecol 50:1131-41.

Baker WL. 2011. Pre-EuroAmerican and recent fire in sagebrush ecosystems. In: Knick ST, Connelly JW, Eds. Greater SageGrouse: Ecology and Conservation of a Landscape Species and its Habitats, Vol. 38Studies in Avian Biology Series, Berkeley: University of California Press. p 185-201.

Balch JK, Bradley BA, D’Antonio CM, Gomez-Dans J. 2013. Introduced annual grass increases regional fire activity across the arid western USA (1980-2009). Glob Change Biol 19:17383.

Beaumont LJ, Hughes L, Pitman AJ. 2008. Why is the choice of future climate scenarios for species distribution modelling important? Ecol Lett 11:1135-46.

Blank RR, Morgan T, Allen F. 2015. Suppression of annual Bromus tectorum by perennial Agropyron cristatum: roles of soil nitrogen availability and biological soil space. AoB PLANTS 7:plv006. doi:10.1093/aobpla/plv006.

Bradford JB, Lauenroth WK. 2006. Controls over invasion of Bromus tectorum: the importance of climate, soil, disturbance and seed availability. J Veg Sci 17:693-704.

Bradley BA. 2009. Regional analysis of the impacts of climate change on cheatgrass invasion shows potential risk and opportunity. Glob Change Biol 15:196-208.

Bradley BA. 2013. Distribution models of invasive plants overestimate potential impact. Biol Invasions 15:1417-29.

Bradley BA, Oppenheimer M, Wilcove DS. 2009. Climate change and plant invasions: restoration opportunities ahead? Glob Change Biol 15:1511-21.

Brooks ML, D'Antonio CM, Richardson DM, Grace JB, Keeley JE, DiTomaso JM, Hobbs RJ, Pellant M, Pyke D. 2004. Effects of alien plants on fire regimes. Bioscience 54:677-88.

Brummer TJ, Maxwell BD, Higgs MD, Rew LJ. 2013. Implementing and interpreting local-scale invasive species distribution models. Divers Distrib 19:919-32.

Buisson L, Thuiller W, Casajus N, Lek S, Grenouillet G. 2010. Uncertainty in ensemble forecasting of species distribution. Glob Change Biol 16:1145-57.

Carson R. 1962. Silent spring. New York: Houghton Mifflin Co.

Chambers JC, Roundy BA, Blank RR, Meyer SE, Whittaker A. 2007. What makes Great Basin sagebrush ecosystems invasible by Bromus tectorum? Ecol Monogr 77:117-45.

Chambers JC, Bradley BA, Brown CS, D'Antonio C, Germino MJ, Grace JB, Hardegree SP, Miller RF, Pyke DA. 2014a. Resilience to stress and disturbance, and resistance to Bromus tectorum L. invasion in cold desert shrublands of western North America. Ecosystems 17:360-75.

Chambers JC, Miller RF, Board DI, Pyke DA, Roundy BA, Grace JB, Schupp EW, Tausch RJ. 2014b. Resilience and resistance of sagebrush ecosystems: implications for state and transition models and management treatments. Rangeland Ecol Manag 67:440-54.
Cooper SV, Lesica P, Kudray GM. 2011. Post-fire recovery of wyoming big sagebrush steppe in Central and Southeast Montana. Nat Resour Env Iss 16:Article 2.

Coulloudon B, Eshelman K, Gianola J, Habich N, Hughes L, Johnson C, and others. 1999. Sampling vegetation attributes. Technical Reference 1734-4. Denver, Colorado: Bureau of Land Management (www.blm.gov/nstc/library/pdf/samplveg. pdf).

Cox RD, Anderson VJ. 2004. Increasing native diversity of cheatgrass-dominated rangeland through assisted succession. Rangeland Ecol Manag 57:203-10.

Cronquist A, Holmgren AH, Holmgren NH, Reveal JL, Holmgren PK. 1972. Intermountain Flora, geological and botanical history, plant geography, vascular cryptogams, gymnosperms, glossary, Vol. 1Bronx: New York Botanical Garden Press.

D'Antonio CM, Vitousek PM. 1992. Biological invasions by exotic grasses, the grass/fire cycle, and global change. Ann Rev Ecol Syst 23:63-87.

Daubenmire R. 1959. A canopy-coverage method of vegetational analysis. Northwest Sci 33:43-64.

Davies GM, Bakker JD, Dettweiler-Robinson E, Dunwiddie PW, Hall SA, Downs J, Evans J. 2012. Trajectories of change in sagebrush steppe vegetation communities in relation to multiple wildfires. Ecol Appl 22:1562-77.

Davies KW, Boyd CS, Beck JL, Bates JD, Svejcar TJ, Gregg MA. 2011. Saving the sagebrush sea: an ecosystem conservation plan for big sagebrush plant communities. Biol Conserv 144:2573-84.

Davies KW, Bates JD, Madsen MD, Nafus AM. 2014. Restoration of mountain big sagebrush steppe following prescribed burning to control Western Juniper. Environ Manag 53:1015-22.

Douglas WO. 1961. My wilderness: East to Katahdin. Garden City: Doubleday.

Efron B. 1983. Estimating the error rate of a prediction rule: improvement on cross-validation. J Am Stat Assoc 78: 316-31.

Elith J, Leathwick JR, Hastie T. 2008. A working guide to boosted regression trees. J Anim Ecol 77:802-13.

Gunnell KL, Monaco TA, Call CA, Ransom CV. 2010. Seedling interference and niche differentiation between crested wheatgrass and contrasting native Great Basin species. Rangeland Ecol Manag 63:443-9.

Haubensak K, D'Antonio C, Wixon D. 2009. Effects of fire and environmental variables on plant structure and composition in grazed salt desert shrublands of the Great Basin (USA). J Arid Environ 73:643-50.

Hijmans RJ, Cameron SE, Parra JL, Jones PG, Jarvis A. 2005. Very high resolution interpolated climate surfaces for global land areas. Int J Climatol 25:1965-78.

Hijmans RJ, Phillips S, Leathwick J, Elith J. 2015a. dismo: species distribution modeling, version 1.0-12. cran.r-project.org/ web/packages/dismo/.

Hijmans RJ, Van Etten J. Mattiuzzi M, Sumner M, Greenberg JA, Lamigueiro OP, and others. 2015b. raster: geographic data analysis and modeling, version 2.3-40. cran.r-project.org/ web/packages/raster/.

Holmgren NH, Holmgren PK, Reveal JL, DE Atha, Spellenberg R, Holmgren $\mathrm{AH}$ et al. 2012. Intermountain Flora, subclasses 
Magnoliidae-Caryophyllideae, Vol. 2ABronx: New York Botanical Garden.

Jones TA, Monaco TA. 2009. A role for assisted evolution in designing native plant materials for domesticated landscapes. Front Ecol Environ 7:541-7.

Knapp PA. 1996. Cheatgrass (Bromus tectorum L.) dominance in the Great Basin Desert. Glob Environ Change 6:37-52.

Knick ST. 1999. Requiem for a sagebrush ecosystem. Northwest Sci 73:53-7.

Knutson KC, Pyke DA, Wirth TA, Arkle RS, Pilliod DS, Brooks ML, Chambers JS, Grace JB. 2014. Long-term effects of reseeding after wildfire on vegetation composition in the Great Basin shrub steppe. J Appl Ecol 51:1414-24.

Lavin M. 1983. Floristics of the upper Walker River, California and Nevada. Great Basin Naturalist 43:93-130.

Lavin M, Seibert C. 2011. Great Plains Flora? Plant geography of eastern Montana's lower elevation shrub-grass dominated vegetation. Natural Resources and Environmental Issues: Vol. 16. Article 2 (http://digitalcommons.usu.edu/nrei/voll6/iss l/ 2).

Lavin M, Brummer TJ, Quire R, Maxwell BD, Rew LJ. $2013 a$. Physical disturbance shapes vascular plant diversity more profoundly than fire in the sagebrush steppe of southeastern Idaho, USA. Ecol Evol 3:1626-41.

Lavin M, Brummer TJ, Seipel T, Maxwell BD, Rew LJ. 2013b. The Intermountain Flora sets the stage for a community phylogenetic analysis of plant biodiversity in the sagebrush steppe of western North America. Mem N Y Bot Gard 108:6384.

Leger EA, Espeland EK, Merrill KR, Meyer SE. 2009. Genetic variation and local adaptation at a cheatgrass (Bromus tectorum) invasion edge in western Nevada. Mol Ecol 18:4366-79.

Lesica P. 2012. Manual of montana vascular plants. Fort Worth: BRIT Press.

Mack RN. 2011. Fifty years of 'waging war on cheatgrass': research advances, while meaningful control languishes. In: Richardson DM, Ed. Fifty years of invasion ecology. Oxford: Wiley. p 253-65.

McDonald A, Riha S, DiTommaso A, DeGaetano A. 2009. Climate change and the geography of weed damage: analysis of US maize systems suggests the potential for significant range transformations. Agric Ecosyst Environ 130:131-40.

Mesgaran MB, Cousens RD, Webber BL. 2014. Here be dragons: a tool for quantifying novelty due to covariate range and correlation change when projecting species distribution models. Divers Distrib 20:1147-59.

Mote P, Brekke L, Duffy PB, Maurer E. 2011. Guidelines for constructing climate scenarios. Eos 92:257-64.

Nafus AM, Svejcar TJ, Ganskopp DC, Davies KW. 2015. Abundances of coplanted native bunchgrasses and crested wheatgrass after 13 years. Rangeland Ecol Manag 68:211-14.

Nelson ZJ, Weisberg PJ, Kitchen SG. 2014. Influence of climate and environment on post-fire recovery of mountain big sagebrush. Int J Wildland Fire 23:131-42.

O'Donnell MS, Ignizio DA. 2012. Bioclimatic predictors for supporting ecological applications in the conterminous United States: u.S. Geol Surv Data Ser 691:1-10.

Parker IM, Simberloff D, Lonsdale WM, Goodell K, Wonham M, Kareiva PM, Williamson MH, Von Holle B, Moyle PB, Byers
JE, Goldwasser L. 1999. Impact: toward a framework for understanding the ecological effects of invaders. Biol Invasions 1:3-19.

Prevéy JS, Seastedt TR. 2014. Seasonality of precipitation interacts with exotic species to alter composition and phenology of a semi-arid grassland. J Ecol 102:1549-61.

PRISM Climate Group. 2015. Oregon State University. http:// prism.oregonstate.edu. Accessed 15 Oct 2015.

Quire R. 2013. The sagebrush steppe of Montana and southeastern Idaho shows evidence of high native plant diversity, stability, and resistance to the detrimental effects of nonnative plant species. M.S. Thesis. Bozeman, Montana: Montana State University.

R Core Team. 2015. R: a language and environment for statistical computing. Vienna, Austria: R Foundation for Statistical Computing. www.R-project.org. Accessed 21 June 2015.

Ratzlaff TD, Anderson JE. 1995. Vegetal recovery following wildfire in seeded and unseeded sagebrush steppe. J Range Manag 46:366-91.

Reheis MC. 1999. Extent of Pleistocene lakes in the western Great Basin. USDI, USGS Miscellaneous Field Studies Map MF-2323.

Reisner MD, Grace JB, Pyke DA, Doescher PS. 2013. Conditions favouring Bromus tectorum dominance of endangered sagebrush steppe ecosystems. J Appl Ecol 50:1039-49.

Ribeiro PJ, Diggle PJ. 2015. geoR: analysis of geostatistical data, version 1.7-5.1. cran.r-project.org/web/packages/geoR/.

Seefeldt SS, McCoy SD. 2003. Measuring plant diversity in the tall threetip sagebrush steppe: influence of previous grazing management practices. Environ Manage 32:234-45.

Seipel TF. 2006. Plant species diversity in the sagebrush steppe of Montana. M.S. Thesis. Bozeman, Montana: Montana State University.

Still SM, Richardson BA. 2015. Projections of contemporary and future climate niche for Wyoming big sagebrush (Artemisia tridentata subsp. wyomingensis): a guide for restoration. Nat Areas J 25:30-43.

Suding KN, Gross KL, Houseman GR. 2004. Alternative states and positive feedbacks in restoration ecology. Trends Ecol Evol 19:46-53.

Taylor K, Brummer T, Rew LJ, Lavin M, Maxwell BD. 2014. Bromus tectorum response to fire varies with climate. Ecosystems 17:960-73.

Tisdale EW, Hironaka M. 1981. The sagebrush-grass region: a review of the ecological literature. Forest, Wildlife and Range Experiment Station, Contribution 209. Moscow: University of Idaho.

Twain M. 1872. Roughing It. Reprinted by the University of California Press, 2011.

Vano JA, Kim JB, Rupp DE, Mote PW. 2015. Selecting climate change scenarios using impact-relevant sensitivities. Geophys Res Lett 42:5516-25.

Welch BL. 2005. Big sagebrush: a sea fragmented into lakes, ponds, and puddles. USDA General Technical Report RMRS144: $1-210$.

Wenger SJ, Olden JD. 2012. Assessing transferability of ecological models: an underappreciated aspect of statistical validation. Methods Ecol Evol 3:260-7. 
Young JA, Sparks BA. 2002. Cattle in the cold desert. Reno: University of Nevada Press.

Young JA, Clements CD. 2009. Cheatgrass: fire and forage on the range. Reno: University of Nevada Press.
Zelikova TJ, Hufbauer RA, Reed SC, Wertin T, Fettig C, Belnap J. 2013. Eco-evolutionary responses of Bromus tectorum to climate change: implications for biological invasions. Ecol Evol 3:1374-87. 